\title{
Aspek Hukum Perusahaan Penyelenggaraan Angkutan Umum Berbasis Teknologi Informasi
}

\author{
Siti Mariyam¹, Markus Suryoutomo² \\ Universitas 17 Agustus 1945 Semarang1, \\ Universitas 17 Agustus 1945 Semarang² \\ sitimariyam@untagsmg.ac.id
}

\begin{abstract}
This paper aims to find out how the legal aspects of companies operating special rental transportation are regulated based on the Regulation of the Minister of Transportation (Permenhub.) of the Republic of Indonesia Number 118 of 2018 which is amended by Permenhub. Number 17 of 2019. Transportation is the movement of people or goods from one place to another by using a vehicle in the road traffic room. The information technology system-based transportation adapum is a mode of transportation in the form of legal entities and micro-enterprises or small-scale business actors connecting from one place of origin to one's destination, where the ordering method uses an information technology system and the amount of the fare is listed in the application. Companies in the form of legal entities in the form of Limited Liability Companies, BUMN, BUMD, and Cooperatives as well as micro business actors or small business actors established in accordance with the provisions of laws and regulations. The form of this special rental transportation company is not in accordance with Law Number 22 of 2009 and Article 79 of Government Regulation Number 74 of 2014 concerning the Implementation of Public Transportation.
\end{abstract}

Key words: public transportation, information technology

\section{Abstrak}

Paparan ini bertujuan untuk mengetahui bagaimana aspek hukum perusahaan penyelenggaraan angkutan sewa khusus yang diatur berdasarkan Peraturan Menteri Perhubungan (Permenhub.) Republik Indonesia Nomor 118 Tahun 2018 yang diubah dengan Permenhub. Nomor 17 Tahun 2019. Angkutan ialah perpindahan orang atau barang dari satu tempat ke tempat lain dengan menggunakan kendaraan di ruang lalu lintas jalan. Adapum angkutan berbasis sistem teknologi informasi adalah salah satu moda transportasi berbentuk badan hukum dan pelaku usaha mikro atau pelaku usaha kecil yang menghubungkan dari satu tempat asal ke tempat tujuan, yang cara pemesananannya menggunakan sistem teknologi informasi dan besarnya tarif sudah tercantum dalam aplikasi. Perusahaan berbentuk badan hukum berupa Perseroan Terbatas, BUMN, BUMD, dan Koperasi serta pelaku usaha mikro atau pelaku usaha kecil yang didirikan sesuai dengan ketentuan peraturan perundang-undangan. Bentuk perusahaan penyelenggara angkutan sewa khusus ini tidak sesuai dengan Undang-Undang Nomor 22 Tahun 2009 dan Pasal 79 Peraturan Pemerintah Nomor 74 Tahun 2014 tentang Penyelenggaraan Angkutan Umum.

Kata kunci : angkutan umum, teknologi informasi 


\section{PENDAHULUAN}

Perkembangan teknologi komunikasi, media dan informatika membuat perubahan kehidupan manusia di bidang ekonomi, sosial, budaya dan politik berubah secara cepat dan signifikan, perubahan di bidang ekonomi, munculnya perdagangan barang dan jasa yang dilakukan masyarakat dengan menggunakan sistem teknologi informasi. Hal ini dimungkinkan karena adanya amanah dalam Undang-Undang Informasi dan Transaksi Elektronik (ITE), bahwa tujuan pemanfaatan teknologi informasi ada 3 (tiga), salah satunya adalah untuk memajukan perdagangan, dibidang jasa angkutan berbasis aplikasi.

Penyelenggaraan angkutan sewa khusus mempunyai peran strategis dalam mendukung pembangunan untuk mewujudkan kesejahteraan umum sebagaimana diamanatkan dalam Undang-Undang Dasar Negara Republik Indonesia Tahun 1945.

Masyarakat membutuhkan kepastian hukum terhadap aspek keselamatan, keamanan, kenyamanan, kesetaraan, keterjangkauan, dan keteraturan atas penyelenggaraan angkutan sewa khusus;

\section{Pasal 11}

(1) Perusahaan angkutan sewa khusus wajib memiliki izin penyelenggaraan angkutan sewa khusus.

Perizinan bagi angkutan sewa khusus diperlukan untuk memberikan legalitas dan kepastian hukum, sesuai dengan pengertian perizinan yaitu pemberian legalitas kepada seseorang atau pelaku usaha kegiatan tertentu, baik dalam bentuk izin maupun tanda daftar usaha. Izin merupakan salah satu instrumen untuk mengatur tingkah laku para warga (Hestanto, 2020).

(2) Izin penyelenggaraan angkutan sewa khusus sebagaimana dimaksud pada ayat (1) dikenakan biaya sebagai penerimaan negara bukan pajak atau retrubusi daerah.

\section{Pasal 12}

(1) Perusahaan angkutan sewa khusus sebagaimana dimaksud dalam Pasal 11 ayat (1)harus berbentuk badan hukum Indonesi.

(2) Badan hukum Inonesia tersebut, berbentuk:
a. Badan Usaha Milik Negara;
b. Badan Usaha Milik Daerah;
c. Perseroan Terbatas;
d. Koperasi.

(3) Selain badan hukum Indonesia, sesuai ketentuan ayat (2), penyelenggara angkutan sewa khusus dapat dilakukan oleh pelaku usaha mikro atau pelaku usaha kecil sesuai dengan ketentuan peraturan perundang-undanga UMKM.

Menurut ketentuan Pasal 79 ayat (2) dan penjelasan pasal demi pasal Peraturan Pemerintah Nomor 74 Tahun 2014 tentang Angkutan Jalan: 
"Bentuk-bentuk badan hukum Indonesia berdasarkan perUndangUndangan yaitu, Badan Usaha Milik Negara (BUMN), Badan Usaha Milik Daerah (BUMD), Perseroan Terbatas (PT), dan Koperasi.oleh karenanya, jika badan hukum Koperasi maka koperasi yang memiliki unit usaha di bidang angkutan jalan. Adapun perizinan di bidang penyelenggaraan angkutan jalan berdasar Undang-Undang dibedakan menjadi tiga yaitu, angkutan orang dalam trayek, angkutan orang tidak dalam trayek, dan penyelenggaraan angkutan barang umum dan angkutan barang khusus.

\section{Konsep Peraturan}

Peraturan berasal dari kata atur, yang berari tatanan (kaidah, ketentuan yang dibuat untuk mengatur. Pengertian peraturan menurut kamus besar Bahasa Indonesia, peraturan ketentuan yang mengikat warga kelompok masyarakat dipakai sebagai panduan, tatanan, dan kendalikan tingkah laku yang sesuai dan diterima setiap warga masyarakat harus mentaati aturan yang berlaku, atau ukuran, kaidah yang dipakai sebagai tolok ukur untuk menilai atau membandingkan sesuatu (KBBI, 2017:76).

Konsep pengaturan penyelenggaraan angkutan khusus yang akan dibangun dalam penelitian ini adalah konsep pengaturan berdasarkan undang-undang.menurut teori stufenbau dari Hans Kelsen, bahwa peraturan perundang-undangan yang lebih rendah tidak boleh bertentangan dengan undang-undang yabg lebih tinggi. Peraturan perundang-undangan harus sesuai dengan hierarki peraturan perundangundangan, seperti tercantum dalam Pasal 7 Undang-Undang Nomor 15 tahun 2019 tentang Peraturan Perundang-undangan sebagai berikut:

1. Undang-Undang dasar Negara Republik Indonesia Tahun 1945.

2. Ketetapan Majelis Permusyawaratan Rakyat.

3. Undang-Undang/Peraturan Pemerintah Pengganti UndangUndang.

4. Peraturan Pemerintah.

5. Peraturan Presiden.

6. Peraturan Daerah Provinsi.

7. Peraturan Daerah Kabupaten/Kota

Fungsi pengangkutan adalah memindahkan barang atau orang dari satu tempat ke tempat lain dengan maksud untuk meningkatkan daya guna dan nilai (Andika, 2016:169). Menurut Abdul Kadir Muhammad, konsep pengangkutan meliputi 3 (tiga) aspek yaitu Abdul Kadir, 1998:1):

1. Pengangkutan sebagai usaha (business);

2. Pengangkutan sebagai perjanjian; dan

3. Pengangkutan sebagai proses (applying process).

Pengangkutan sebagai usaha (business) mempunyai ciri-ciri yaitu berdasarkan perjanjian, kegiatan ekonomi di bidang jasa, berbentuk perusahaan, dan menggunkan alat angkut mekanik. Pengangkutan sebagai 
perjanjian pada umumnya bersifat lisan (tidak tertulis) tetapi selalu didukung oleh dokumen perjanjian. Perjanjian pengangkutan dapat juga tertulis yang disebut perjanjian carter. Adapun perjanjian sebagai proses yaitu serangkaian perbuatan mulai dari pemuatan ke dalam alat pengangkut, kemudian dibawa menuju ke tempat yang telah ditentukan, dan pembongkaran atau penurunan di tempat tujuan (Abdul Kadir, 1998:12-13).

Istilah pengangkutan biasa pula disebut dengan transportasi terjemahan kata dalam bahasa Inggris transportation. Pengangkutan lebih menekankan pada aspek yuridis sedangkan transportasi lebih menekankan pada aspek kegiatan perekonomian, akan tetapi keduanya memiliki makna yang sama, yaitu sebagai kegiatan pemindahan dengan menggunakan alat angkut. Asas-asas hukum pengangkutan dikalsifikasikan menjadi dua yaitu (Melkianus, 2019):

1. Yang bersifat publik, dan

2. Yang bersifat perdata.

Asas-asas hukum pengangkutan yang bersifat publik terdapat pada tiap-tiap undang-undang pengangkutan baik darat, udara, maupun laut. Dalam pengangkutan jalan asas-asas yang publik terdapat dalam Pasal 2 Undang-undang Nomor 22 Tahun 2009 tentang Lalu Lintas dan Angkutan Jalan yaitu:

1. Asas transparan

Dalam penjelasan pasal demi pasal Undang-undang lalu Lintas dan Angkutan jalan dijelaskan yang dimaksud dengan asas transparan adalah keterbukaan dalam penyelenggaraan lalu lintas dan angkutan jalan kepada masyarakat luas dalam memperoleh informasi yang benar, jelas, dan jujur sehingga masyarakat mempunyai kesempatan berpartisipasi bagi pengembangan lalu lintas dan angkutan jalan.

2. Asas akuntabel

Asas akuntabel adalah penyelenggaraan lalu lintas dan angkutan jalan yang dapat dipertanggungjawabkan.

3. Asas berkelanjutan

Asas berkelanjutan adalah penjaminan kualitas fungsi lingkungan melalui pengaturan persyaratan teknis laik kendaraan dan rencana umum pembangunan serta pengembangan jaringan lalu lintas dan angkutan jalan.

4. Asas partisipatif

Asas partisipatif adalah pengaturan peran serta masyarakat dalam proses penyusunan kebijakan, pengawasan terhadap pelaksanaan kebijakan, penanganan kecelakaan, dan pelaporan atas peristiwa yang terkait dengan lalu lintas dan angkutan jalan.

5. Asas bermanfaat 
Asas bermanfaat adalah semua kegiatan penyelenggaraan lalu lintas dan angkutan jalan yang dapat memberikan nilai tambah sebesar-besarnya dalam rangka mewujudkan kesejahteraan masyarakat.

6. Asas efisien dan efektif.

Asas efisien dan efektif adalah pelayanan dalam penyelenggaraan lalu lintas dan angkutan jalan yang dilakukan oleh setiap pembina pada jenjang pemeritahan secara berdaya guna dan berhasil guna.

7. Asas seimbang.

Asas seimbang adalah penyelenggaraan lalu lintas dan angkutan jalan yang harus dilaksanakan atas dasar keseimbangan antara sarana dan prasarana serta pemenuhan hak dan kewajiban pengguna jasa dan penyelenggara.

8. Asas terpadu.

Asas terpadu adalah penyelenggaraan pelayanan lalu lintas dan angkutan jalan yang dilakukan dengan mengutamakan keserasian dan kesalingbergantungan kewenangan dan tanggung jawab antar instansi pembina.

9. Asas mandiri.

Asas mandiri adalah upaya penyelenggaraan lalu lintas dan angkutan jalan melalui pengembangan dan pemberdayaan sumber daya nasional.

Kesembilan asas publik tersebut di atas yang termuat dalam Pasal 2 Undang-undang Lalu Lintas dan Angkutan jalan menjadi dasar pedoman bagi penyelenggaraan dan pengaturan sarana dan prasarana lalu lintas dan angkutan jalan serta pemenuhan hak dan kewajiban bagi pengguna jasa dan penyelengara angkutan termasuk dalam penyelenggaraan angkutan sewa khusus.

Menurut Abdul Kadir Muhammad, asas-asas pengangkutan yang bersifat perdata sebagai berikut (Melkianus, 2019:18-19):

1. Konsensual.

Pengangkutan tidak diharuskan dalam bentuk tertulis, sudah cukup dengan kesepakatan pihak-pihak. Tetapi untuk menyatakan bahwa perjanjian itu sudah terjadi atau sudah ada harus dibuktikan dengan atau didukung oleh dokumen angkutan. Dokumen angkutan dapat berupa karcis atau tiket.

2. Koordinatif

Pihak-pihak dalam pengangkutan mempunyai kedudukan setara atau sejajar, tidak ada pihak yang membawahi yang lain. Walaupun pengangkut menyediakan jasa dan melaksanakan perintah penumpang/pengirim barang, pengangkut bukan bawahan penumpang/pengirim barang. Pengangkutan adalah perjanjian pemberian kuasa. 
3. Campuran

Pengangkutan merupakan campuran dari tiga jenis perjanjian yaitu perjanjian pemberian kuasa, penyimpanan barang, dan melakukan pekerjaan dari pengirim kepada pengangkut. Ketentuan ketiga jenis perjanjian ini berlaku pada pengangkutan, kecuali jika ditentukan lain dalam perjanjian pengangkutan.

4. Retensi

Pengangkutan tidak menggunakan hak retensi. Hak retensi adalah hak dari penerima kuasa untuk menahan sesuatu yang menjadi milik pemberi kuasa karena pemberi kuasa belum membayar kepada penerima kuasa yang timbul dari pemberian kuasa. Penggunaan hak retensi bertentangan dengan tujuan dan fungsi pengangkutan. Pengangkutan hanya mempunyai kewajiban menyimpan barang atas biaya pemiliknya.

5. Pembuktian dengan dokumen

Setiap pengangkutan selalu dibuktikan dengan dokumen angkutan. Tidak ada dokumen angkutan berarti tidak ada perjanjian pengangkutan, kecuali jika kebiasaan yang sudah berlaku umum, misalnya pengangkutan dengan angkutan kota (angkot) tanpa karcis/tiket penumpang. Dalam angkutan sewa khusus, perjanjian pengangkutan berbentuk perjanjian elektronik.

Tujuan pengangkutan tertuang dalam Pasal 3 Undang-undang Nomor 22 Tahun 2009 yang menyatakan penyelenggaraan lalu lintas dan angkutan jalan diselenggarakan dengan tujuan:

1. Terwujudnya pelayanan lalu lintas dan angkutan jalan yang aman, selamat, tertib, lancar, dan terpadu dengan moda transportasi lain untuk mendorong perekenomian nasional, memajukan kesejahteraan umum, memperkukuh persatuan dan kesatuan bangsa, serta mampu menjunjung tinggi martabat bangsa;

2. Terwujudnya etika berlalu lintas dan budaya bangsa; dan

3. Terwujudnya penegakan hukum dan kepastian hukum bagi masyarakat.

4. Menurut Abdul Kadir Muhammad, subyek hukum adalah pendukung hak dan kewajiban. Subyek hukum pengangkutan niaga adalah pendukung kewajiban dan hak dalam hubungan hukum pengangkutan niaga, yaitu pihak-pihak dalam perjanjian pengangkutan niaga dan pihak-pihak yang berkepentingan dalam pengangkutan niaga (Abdul Kadir, 1998:45-46).

5. Pihak-pihak dalam perjanjian pengangkutan niaga adalah pihakpihak yang secara langsung terikat memenuhi kewajiban dan memperoleh hak dalam perjanjian pengangkutan niaga. Pihakpihak tersebut yaitu, pertama, pengangkut yang berkewajiban pokok menyelenggarakan pengangkutan dan berhak atas biaya 
angkutan; kedua, pengirim yang berkewajiban pokok membayar biaya angkutan dan berhak atas penyelenggaraan pengangkutan barang: ketiga. Penumpang yang berkewajiban pokok membayar biaya angkutan dan berhak atas penyelenggaraan angkutan.

6. Pihak-pihak yang secara tidak langsung terikat pada perjanjian pengangkutan niaga karena bukan pihak, melainkan bertindak atas nama atau untuk kepentingan pihak lain, seperti ekspeditur, agen perjalanan, pengusaha muat bongkar, pengusaha pergudangan, dan penerima yaitu pihak memperoleh hak dalam perjanjian pengangkutan niaga.

\section{Perseroan Terbatas (PT)}

Perseroan terbatas merupakan badan hukum yang besarnya modal tercantum dalam anggaran dasar. Kekayaan perusahaan terpisah dari kekayaan pribadi pemilik, sehingga perusahaan memiliki harta kekayaan sendiri. Tindakan perseroan bukanlah tindakan pemilik atau pemegang saham karena PT dianggap bertindak sendiri yang diwakili oleh dewan direksi (pengurus). Setiap orang dapat memiliki lebih dari satu saham yang menjadi bukti pemilikan atas perusahaan. Pemilik saham mempunyai tanggung jawab yang terbatas yaitu sebanyak saham yang dimiliki (Agustinus, 2019:56-57).

Istilah "terbatas" dalam perseroan terbatas memiliki makna bahwa pemilik atau pemegang saham mempunyai tanggung jawab yang terbatas yaitu, sebanyak saham yang dimiliki di perusahaan tersebut. Artinya, apabila perusahaan mempunyai utang melebihi kekayaan perusahaan maka kelebihan utang tersebut tidak menjadi tangung jawab para pemegang saham. Namun tanggung jawab menjadi tidak terbatas jika pemegang saham ikut campur (intervensi) ke dalam perseroan hingga perseroan mengalami kerugian. Pengurus (dewan direksi) dan dewan komisaris juga tidak ikut bertanggung jawab sampai harta kekayaan pribadinya. Apabila perusahaan mendapat keuntungan, maka keuntungan tersebut dibagikan sesuai dengan ketentuan yang ditetapkan. Pemilik saham akan memperoleh bagian keuntungan (deviden) yang besarnya tergantung pada besar-kecilnya keuntungan yang diperoleh perseroan terbatas.

Pendirian sebuah perseroan terbatas harus dengan menggunakan Akta Notaris yang di dalamnya harus mencantumkan hal-hal sebagai berikut (Agustinus, 2019:57):

1. Nama dari Perseroan Terbatas

2. Modal dan Bidang Usaha

3. Alamat perusahaan dan syarat lain-lainnya sebagaimana diatur dalam Undang-Undang Nomor 40 Tahun 2007 Tentang Perseroan Terbatas. 
Akta sebuah perseroan terbatas harus disahkan oleh Menteri Hukum dan Hak Asasi Manuusia (Hukum dan HAM) Republik Indonesia. Untuk mendapat izin dari Menteri Hukum dan HAM, perusahaan harus memenuhi persyaratan sebagai berikut:

1. Tujuan dan kegiatan perseroan terbatas tidak bertentangan dengan ketertiban umum dan kesusilaan.

2. Akta pendirian memenuhi syarat yang ditetapkan Undangundang.

3. Modal dasar pendirian perseroan terbatas minimal Rp. 50.000.000,(lima puluh juta rupiah). Kemudian minimal modal yang ditempatkan dan disetor ke perseroan ialah sebesar $25 \%$ dari modal dasar (Pasal 32 dan 33 UU Nomor 40 Tahun 2007).

Kemudian pengumuman tentang perseroan dilakukan dalam Berita Negara Republik Indonesia, yang merupakan kewenangan/kewajiban Menteri Hukum dan HAM, sedangkan perubahan anggaran dasar wajib dibuat secara notariil dan setiap perubahan dimaksud harus mendapat pengesahan dari Menteri Hukum dan HAM serta diumumkan dalam Berita Negara dan Tambahan Berita Negara dalam hal melakukan perubahan terhadap: nama perseroan terbatas, maksud dan tujuan, kegiatan usaha, jangka waktu, besarnya modal dasar, pengurangan modal ditempatkan dan modal yang disetor, serta status perseroan tertutup menjadi perseroan terbuka (tbk) dan sebaliknya (Agustinus, 2019:58).

Di luar yang disebutkan di atas, cukup dilaporkan dan/atau diberitahukan saja kepada Menteri Hukum dan HAM, dan perlu diingat bahwa perbuatan hukum yang dilakukan oleh Direksi, Komisaris dan Pemegang saham atas nama perseroan terbatas sebelum perseroan terbatas memperoleh status badan hukum menjadi tanggung jawab pemilik secara tanggung renteng. Adapun jenis-jenis perseroan terbatas adalah sebagi berikut (Agustinus, 2019:57).

1. PT Tertutup, arinya sahamnya belum dijual ke public;

2. PT Terbuka artinya sebagian sahamnya telah dijual ke publik;

3. PT dalam rangka Penanaman Modal Dalam Negeri (PMDN);

4. Perseroan jenis ini umumnya bergerak di bidang pertanian, perikanan, kelautan, pertambangan, pariwisata, transportasi, dan lain-lain yang bertujuan untuk membantu program pembangunan yang dijalankan pemerintah;

5. PT dalam rangka Penanaman Modal Asing (PMA), seperti PT Freeport, PT Newmont Nusa Tenggara, dan PT Otsuka Indonesia.

6. PT Persero (BUMN/BUMD).

\section{Badan Usaha Milik Negara dan Daerah (BUMN dan BUMD)}

Badan Usaha Milik Daerah diatur dalam Undang-Undang Nomor 19 Tahun 2003. Pengertian BUMN, menurut Pasal 1 angka 1 undang-undang 
ini, BUMN adalah badan usaha yang seluruhnya atau sebagian besar modalnya dimiliki oleh negara melalui penyertaan secara langsung yang berasal dari kekayaan negara yang dipisahkan. Kalau di daerah disebut istilah Badan Usaha Milik Daerah (BUMD) yang sahamnya dimiliki oleh pemerintah daerah.

Maksud dan tujuan pendirian BUMN dapat dilihat dalam ketentuam Pasal 2 ayat (1), yaitu:

1. Memberikan sumbangan bagi perkembangan perekonomian nasional pada umumnya dan penerimaan negara pada khussunya.

2. Mengejar keuntungan.

3. Menyelenggarakan kemanfaatan umum berupa penyediaan barang dan/atau jasa yang bermutu tinggi dan memadai bagi pemenuhan hajat hidup orang banyak.

4. Menjadi perintis kegiatan-kegiatan usaha yang belum dapat dilaksanakan oleh sektor swasta dan koperasi.

5. Turut aktif memberikan bimbingan dan bantuan kepada pengusaha golongan ekonomi lemah, koperasi, dan masyarakat.

Adapun modal BUMN terdiri dari:

1. Kekayaan negara yang dipisahkan.

2. Penyertaan modal negara dalam rangka pendirian atau penyertaan pada BUMN bersumber dari Anggaran Pendapatan dan Belanja Negara (APBN) dan kapitalisasi cadangan/sumber lainnya.

3. Setiap penyertaan modal negara dalam rangka pendirian BUMN atau perseroan terbatas yang dananya berasal dari APBN ditetapkan dengan Peraturan Pemerintah. Setiap perubahan penyertaan modal negara baik berupa penambahan maupun pengurangan, termasuk perubahan struktur kepemilikan negara atas saham persero atau perseroan terbatas, ditetapkan dengan peraturan pemerintah.

BUMN terdiri atas persero dan perum. Perusahaan perseroan (Persero) adalah BUMN yang berbentuk perseroan terbatas yang modalnya terbagi dalam saham yang seluruh atau paling sedikit $51 \%$ (lima puluh satu persen) sahamnya dimiliki oleh negara yang tujuan utamanya adalah mengejar keuntungan. Maksud dan tujuan pendirian persero adalah: (a) menyediakan barang/jasa yang bermutu tinggi dan berdaya saing kuat; (b) mengejar keuntungan guna meningktakan nilai perusahaan.

Organ BUMN persero sama dengan organ perseroan terbatas (PT) pada umumnya, yaitu adanya Rapat Umum Pemegang Saham (RUPS) ebagi organ tertinggi, Dewan Direksi (pelaksana operasional perusahaan) serta Dewan Komisaris (pengawas). Contoh BUMN Persero adalah PT Garuda Indonesia, PT Kereta Api Indonesia.

BUMN yang berupa perusahaan umum (Perum) adalah BUMN yang seluruh modalnya dimiliki negara dan tidak terbagi atas saham, yang 
bertujuan untuk kemanfaatan umum berupa penyediaan barang dan/atau jasa yang bermutu tinggi dan sekaligus mengejar keuntungan berdasarkan prinsip pengelolaan perusahaan. Maksud dan tujuan perum adalah menyelenggarakan usaha yang bertujuan untuk kemanfataan umum berupa penyediaan barang dan/atau jasa yang berkualitas dengan harga yang terjangkau oleh masyarakat berdasarkan prinsip pengelolaan perusahaan yang sehat. Organ perum terdiri dari Menteri yang terkait dengan bidang usaha, direksi dan dewan pengawas.

Menurut Augustinus Simanjuntak, berdasarkan Undang-Undang Nomor 40 Tahun 2007 tentang Perseroan Terbatas, PT merupakan asosiasi modal yang dalam menjalankan usahanya memiliki tanggung jawab mandiri. Artinya pemerintah sebagai sebagai pemegang saham mayoritas tidak perlu ikut campur (intervensi) dalam mengendalikan kegiatan bisnis BUMN. Pemerintah hanya bertanggung jawab atas kepemilikan saham, menentukan arah kebijakan umum BUMN, meminta target point, dan laporan pertanggungjawaban dewan direksi dan komisaris (Agustinus, 2019:64-65).

Kemandirian usaha juga perlu diterapkan pada perusahaan daerah (BUMD). Motor pembangunan ekonomi nasional tidak hanya BUMN tetapi juga BUMD, yang sebagian besar sahamnya dimiliki oleh Pemerintah Daerah (Pemda). Pemda sebagai pemilik mayoritas saham BUMD (Persero) perlu menjaga kemandirian BUMD sebagaimana telah ditetapkan pada BUMN.

\section{Koperasi}

Koperasi yang dimaksud di sini bukanlah koperasi yang sudah mulai banyak menyimpang karena berubah fungsi sebagai pemberi pinjaman berbunga tinggi bagi warga ekonomi lemah. Semangat koperasi sudah seharusnya dikembalikan pada semangat yang sesungguhnya yaitu kekeluargaan dan gotong royong. Oleh karena itu Undang Undang Nomor 17 tahun 2012 tentang Perkoperasian telah dibatalkan oleh Mahkamah Konstitusi (MK) karena dianggap berjiwa korporasi yang bisa berujung pada kapitalisasi koperasi lewat investasi, sehingga bisa menggerus kemandiriannya, karena itu MK memutuskan untuk kembali ke UndangUndang Nomor 25 Tahun 1992 tentang Perkoperasian (Agustinus, 2019:61).

Menurut Undang-Undang Nomor 25 tahun 1992, koperasi bertujuan untuk mensejahterakan anggotanya. Fungsi dan peran koperasi sebagai berikut:

1. Membangun dan mengembangkan potensi dan kemampuan ekonomi anggota pada khususnya dan masyarakat pada umumnya untuk meningkatkan kesejahteraan ekonomi dan sosialnya. 
2. Berperan serta secara aktif dalam upaya mempertinggi kualitas kehidupan manusia dan masyarakat.

3. Memperkokoh perekonomian rakyat sebagai dasar kekuatan dan ketahanan perekonomian nasional dengan koperasi sebagai soko gurunya.

4. Berusaha untuk mewujudkan dan mengembangkan perekonomian nasional yang merupakan usaha bersama berdasarkan asas kekeluargaan dan demokrasi ekonomi.

Syarat-syarat pembentukan koperasi sebagai berikut:

1. Dibentuk oleh sekurng-kurangnya 20 (dua puluh) orang.

2. Berdasarkan akta pendirian.

3. Kedudukan di wilayah Indonesia.

Adapun status badan hukum koperasi yaitu:

1. Akta pendirian disahkan oleh dinas Koperasi setempat.

2. Setelah disahkan koperasi mendapatkan Surat Keputusan (SK) pengesahan dari Menteri Koperasi.

3. Akta pendirian dan pengesahannya diumumkan dalam Berita Negara Republik Indonesia dan Tambahan Berita Negara Republik Indonesia.

4. Akta pendirian dan perubahan koperasi dibuat secara notariil.

Perangkat organisasi koperasi terdiri dari rapat anggota, pengurus dan pengawas. Masing-masing memiliki tugas dan wewenang sebagai berikut:

1. Rapat Anggota (Pearangkat Tertinggi) yang berwenang menetapkan Anggaran Dasar (AD), memilih pengurus dan pengawas, pemberhentian pengurus dan pengawas, membuat rencana kerja, rencana anggaran pendapatan, dan lain-lain. Rapat anggota koperasi dilakukan paling sedikit 1 (satu) tahun sekali.

2. Pengurus (pelaksana harian/operasional) yang dipilih oleh anggota koperasi dengan masa jabatan 5 (lima) tahun.

3. Pengawas, yang dipilih oleh anggota untuk mengawasi jalannya kegiatan koperasi.

\section{Usaha Mikro, Kecil dan Menengah (UMKM)}

Badan usaha penyelenggara angkutan sewa khusus, menurut Permenhub. Nomor 118 Tahun 2018 Pasal 12 ayat (3) selain badan hukum Indonesia yang berbentuk Badan Usaha Milik Negara, Badan Usaha Milik Daerah, Perseroaan Terbatas atau Koperasi, juga dapat dilakukan oleh pelaku usaha mikro atau pelaku usaha kecil sesuai dengan peraturan perundang-undangan. Peraturan perundang-undangan tersebut yaitu Undang-Undang Nomor 20 Tahun 2008 tentang Usaha Mikro, Kecil, dan Menengah (UMKM). 
Pengertian usaha mikro dapat dijumpai dalam Pasal 1 angka 1 Undang-Undang UMKM, bahwa usaha mikro adalah usaha produktif milik orang perorangan dan/atau badan usaha perorangan yang memenuhi kriteria usaha mikro sebagaimana diatur dalam UndangUndang UMKM. Adapun dalam Pasal 1 angka 2 memuat pengertian usaha kecil adalah usaha ekonomi produktif yang berdiri sendiri, yang dilakukan oleh orang perorangan atau badan usaha yang bukan merupakan anak perusahaan atau bukan cabang perusahaan yang dimiliki, dikuasai, atau menjadi bagian baik langsung maupun tidak langsung dari usaha menengah atau usaha besar yang memenuhi kriteria usaha kecil sebagaimana dimaksud undang-undang.

Kriteria usaha mikro, kecil dan menengah diatur dalam Pasal 6 Undang-Undang Usaha Mikro, Kecil dan Menengah (UMKM) yaitu:

(1) Kriteria usaha mikro, sebagai berikut:

a. Memiliki kekayaan bersih paling banyak Rp. 50.000.000,00 (lima puluh juta rupiah), tidak termasuk tanah dan bangunan tempat usaha; atau

b. Memilik hasil penjualan tahunan paling banyak Rp. 300.000.000,00 (tiga ratus juta rupiah).

Dalam penjelasan Pasal 6 ayat (1) huruf a, yang dimaksud dengan kekayaan bersih adalah hasil pengurangan total nilai kekayaan usaha (aset) dengan total nilai kewajiban, tidak termasuk di dalamnya tanah dan tempat usaha. Adapun dalam penjelasan Pasal 6 ayat (2) huruf b, yang dimaksud dengan hasil penjualan tahunan adalah hasil pejualan bersih (netto) yang berasal dari penjualan barang dan jasa usaha dalam satu tahun.

(2) Kriteria usaha kecil, sebagai berikut:

a. Memiliki kekayaan bersih lebih dari Rp. 50.000.000,00 (lima puluh juta rupiah sampai dengan paling banyak Rp. 500.000.000,00 (lima ratus juta rupiah), tidak termasuk tanah dan bangunan tempat usaha; atau

b. Memiiki hasil penjualan tahunan lebih dari: Rp. 300.000.000,00 (tiga ratus juta rupiah) sampai dengan paling banyak Rp. 2.500.000.000,00 (dua milyar lima ratus juta rupiah) .

(3) Kriteria usaha menengah, sebagai berikut:

a. Memiliki kekayaan bersih lebih dari Rp. 500.000.000,00 (lima ratus juta rupiah) sampai dengan paling banyak Rp. 10.000.000.000,00 (sepuluh milyar rupiah), tidak termasuk tanah dan bangunan tempat usaha; atau

b. Memiliki hasil penjualan tahunan lebih dari: Rp. 2,500.000.000,00 (dua milyar lima ratus juta rupiah) sampai dengan paling banyak Rp. 50.000.000.000,00 (lima puluh milyar rupiah).

Dalam Pasal 12 ayat (3) Permenhub. Nomor 118 tahun 2018, yang dapat menjadi penyelenggara angkutan sewa khusus adalah pelaku usaha 
Aspek Hukum Perusahaan Penyelenggaraan Angkutan umum Berbasis Teknologi Informasi

mikro dan pelaku usaha kecil. Sementara itu pelaku usaha menengah tidak dapat sebagai penyelenggara angkutan sewa khusus.

\section{DAFTAR PUSTAKA}

\section{BUKU}

A Mukti Fajar, 2016, Teori-Teori Hukum Kontemporer, Edisi Revisi, Malang, Setara Press.

Abbas S, 2004, Manajemen Transportasi Nasional, Jakarta, PT Raja Grafindo Persada.

Abdulkadir Muhammad, 1998, Hukum Pengangkutan Niaga, Bandung, Citra Aditya Bakti.

Abdul Manan, 2018, Peranan Hukum Dalam Pembangunan Ekonomi,Cetakan Ketiga, Jakarta, Kencana.

Abdul R. Saliman, 2011, Hukum Bisnis Untuk Perusahaan: Teori dan Contoh Kasus, Cetakan Keenam, Jakarta, Kencana Prenada Media Group.

Abdul Djamali,2001, Pengantar Hukum Indonesia, Edisi 2 Cetakan 7, Jakarta, RajaGrafindo Persada.

Andika Wijaya, 2016, Aspek Hukum Bisnis Transportasi Jalan Online, Jakarta, Sinar Grafika.

Arus Akbar Silondae dan Wirawan B. Ilyas, 2013, Pokok-Pokok Hukum Bisnis, Jakarta, Karya Salemba Empat.

Asyhadie Zaeni, 2005, Hukum Bisnis, Prinsip dan Pelaksanannya Di Indonesia, Jakarta, Rajagrafindo Persada.

Augustinus Simanjutak, 2019, Hukum Bisnis: Sebuah Pemahaman Integratif Antara Hukum dan Praktik Bisnis, Jakarta, Raja Grafindo Persada.

B.Natipulu, 1973, Ekonomi Transportasi, Jakarta, Universitas Kristen Indonesia.

Budi Untung, 2012, Hukum dan Etika Bisnis, Yogyakarta, CV Andi Offset.

C.S.T.Kansil, 1992, Hukum Perusahaan Indonesia, Jakarta, Pradnya Paramitra.

C.S.T.Kansil dan Christine S.T Kansil, 1995, Hukum Perusahaan Indonesia (Aspek Hukum Dalam Ekonomi), Jakarta, Pradnya Paramita.

Dikdik M.Arief Mansur dan Elisatris Gultom, 2009, Cyber Law: Aspek Hukum Teknologi Informasi, Bandung, Refika Aditama.

Dominikus Plato, 2010, Filsafat Hukum, Mencari, Menemukan, dan Memahami Hukum, Surabaya, Laksbang Yustisia.

E. Fernando M Manuliang, 2007, Menggapai Hukum Berkeadilan, Jakarta, Buku Kompas.

Edy Santoso, 2018, Pengaruh Globalisasi Terhadap Hukum Bisnis Di Indonesia, Jakarta Timur, Kencana.

Esmi Warassih, 2005, Pranata Hukum Sebuah Telaah Sosiologis, Semarang, Suryandaru. 
Etta Mamang Sangadji dan Sopiah, 2013, Perilaku Konsumen: Pendekatan Praktis Disertai Himpunan Jurnal Penelitian, Yogyakarta, Andi Offset.

Faisal Santiago, 2012, Pengantar Hukum Bisnis, Jakarta, Mitra Wacana Media.

Firman Tumantara Endipradja, 2016, Hukum Perlindungan Konsumen: Filosofi Perlindungan Konsumen Dalam Perspektif Hukum Negara Kesejahteraan, Malang, Setara Press.

H.A.Abbas Salim, 2013, Manajemen Transportasi, Jakarta, Raja Grafindo Persada.

H.M.N. Purwosutjipto, 1999, Pengertian Pokok Hukum Dagang Indonesia I,: Pengetahuan Dasar Hukum Dagang, Jakarta, Djambatan.

H.R. Daeng Naja, 2009, Pengantar Hukum Bisnis Indonesia, Jakarta, Buku Kita.

Haris Turino, 2016, Meretas Konsep Ekonomi Berbagi (Unveilling The Cocept of Sharing Economy), Tangerang Selatan, Kesuma Putra Kratif.

Harjono K, 2007, Hukum Penanaman Modal, jakarta, Rajagrafindo Persada.

Hans Kelsen, Penerjemah Rainul Mutaqien, 2016, Teori Hukum Murni, Dasar-Dasar Ilmu Hukum Normatif, Cetakan XVI, Bandung, Nusa Media.

Head John W, 2002, Pengantar Umum Hukum Ekonomi, Jakarta, Elips.

Helmi A, 2007, Pengaruh Manajemen Transportasi Terhadap Sistem Transportasi Serta Variabel Moderatornya (studi Pada Transportasi Darat Provinsi Riau), Disertasi (Tidak Dipublikasikan), Malang, Program Pasca Sarjana, Universitas Brawijaya.

Jamin Ginting, 2007, Hukum Perseroan Terbatas: Ulasan Tentang UndangUndang Nomor 40 Tahun 2007, Bandung, Citra Aditya.

Jonathan Sarwono dan K Prihartono, 2012, Perdagangan Online: Cara Bisnis Di Internet, Jakarta, PT Elex Media Komputindo,

Joti K.C, dan Kent L.B, 2005, Dasar-Dasar Rekayasa Transportasi, Jakarta, Erlangga.

M Djaya Bakri, 2016, Transportasi Multimoda: Sebuah Pemodelan Kebutuhan Transportasi Multimedia, Malang, Intimedia.

Maria Farida Indrati, 2011, Ilmu Perundang-Undangan (1) Jenis, Fungsi, dan Rhenald Kasali, 2018, The Great Shifting Series On Disruption: Lebih Baik Pegang kendali Daripada Dikuasai, Jakarta, Gramedia Pustaka Utama.

2019, Disruption: Tak Ada Yang Tak Bisa Diubah Sebelum Dihadapi Motivasi Saja Tidak Cukup, Jakarta, Gramedia Pustaka Utama.

2017, Ilmu Perundang-Undangan (2): Proses dan Teknik Pembentukannya, Yogyakarta, kanisius. 
Aspek Hukum Perusahaan Penyelenggaraan Angkutan umum Berbasis Teknologi Informasi

Mega Erianti Renouw, 2017, Perlindungan Hukum E-Commerce: Perlindungan Hukum Pelaku Usaha \& Konsumen E-Commerce Di Indonesia, Singapura dan Australia, Jakarta, Percetakan Pramuka Grafika.

Muchtarudin Siregar, 1990, Ekonomi dan Manajemen Pengangkutan, Fakultas Ekonomi, Uninversitas Indonesia.

Niniek Suparni, 2009, Cyberspace: Problematika dan Antisipasi Pengaturannya, Jakarta, Sinar Grafika.

Siswanto Sunarso, 2009, Hukum Informasi Dan Transaksi Elektronik (Studi Kkasus Prita Mulyasari), Jakarta, Rieneka Cipta.

Tamin OZ, 2008, Perencanaan, Permodelan \& Rekayasa Transportasi, (Teori, Contoh Soal, dan Aplikasi), Bandung, Penerbit Institut Teknologi Bandung.

\section{PERATURAN PERUNDANG-UNDANGAN}

Kitab Udang-Undang Hukum Perdata

Kitab Undang-Undang Hukum Dagang

Undang-Undang Dasar Negara Republik Indonesia Tahun 1945

Undang-Undang Nomor 25 Tahun 1992 Tentang Perkoperasian

Undang-Undang Nomor 19 Tahun 2003 Tentang Badan Usaha Milik

Negara

Undang-Undang Nomor 40 Tahun 2007 Tentang Perseroan Terbatas

Undang-Undang Nomor 19 Tahun 2016 Tentang Informasi dan Transaski Elektronik

Undang-Undang Nomor 20 tahun 2008 Tentang Usaha Mikro, Kecil dan Menengah

Undang-Undang Nomor 22 Tahun 2009 Tentang Lalu Lintas dan Angkutan Jalan

Undang-Undang Nomor 12 Tahun 2011 Tentang Pembentukan Peraturan Perundang-undangan

Peraturan Pemerintah Republik Indonesia Nomor 82 Tahun 2012 Tentang

Penyelenggaraan Sistem dan Transaksi Elektronik

Peraturan Pemerintah Republik Indonesia Nomor 74 Tahun 2014 Tentang Angkutan Jalan

Peraturan Pemerintah Nomor 24 Tahun 2018 Tentang Pelayanan Perizinan

Berusaha Terintegrasi Secara elektronik

Peraturan Menteri Perhubungan Nomor 26 Tahun 2017 Tentang Penyelengaraan Angkutan Orang Dengan Kendaraan Bermotor Umum Tidak Dalam Trayek

Peraturan Menteri Perhubungan Nomor 108 Tahun 2017 Tentang Penyelengaraan Angkutan Orang Dengan Kendaraan Bermotor Umum Tidak Dalam Trayek

Peraturan Menteri Perhubungan Nomor 118 Tahun 2018 Tentang Penyelengaraan Angkutan Sewa Khusus 